\title{
Perception of Botswana lawyers about the use of ICTs in law firms in Botswana
}

\author{
Madeleine Fombad' \\ Tlokweng DaySpring School, Gaborone, Botswana \\ Fombadm@yahoo.co \\ and \\ Kgomotso H. Moahi ${ }^{2}$ \\ Department of Library and Information Studies, University of Botswana. \\ Moahikh@mopipi.ub.bw
}

\begin{abstract}
Received: I th $^{\text {th }}$ March 2005
Accepted: $6^{\text {th }}$ October 2005

The study was carried out at the University of Botswana to establish the perceptions held by lawyers of ICT and whether these had any bearing on the adoption and use levels of information and communication technology (ICT) by lawyers in Botswana. The objectives of this study were to identify the range of ICT used in the law firms; determine how they were being used and establish their level of usage. The study also investigated the factors that promote or inhibit the adoption and use of ICT. The survey research design was used for the study. All the $1 / 4$ partners in the 59 law firms in Gaborone, the capital city, were included in the survey. Semi structured questionnaires and interview schedules were used to collect both qualitative and quantitative data. The study revealed that law firms are still at early stages of adoption and use of ICT. The lawyers appear to be positively inclined towards Rogers (199I) attributes of an innovation though they remain low adopters. However, lawyers' perception towards ICT was not the overriding factor that determined the adoption and use of ICT in the law firms. The lack of in-house expertise, high cost of ICT consultants, the lack of interest and skills in $I C T$, lack of information about appropriate software, and limited financial resources were other major factors that determined the adoption and use of ICT. The firm size, high cost of legal systems, dissatisfaction with ICT consultants, and lack of time for training also determined the adoption and use pattern of ICT.
\end{abstract}

Key Words: Lawyers; Information Seeking; Information and Communication Technologies; Law Firms; Legal Information

\section{Background}

Botswana is a country in southern Africa. It shares a border with South Africa, Namibia, Zambia and Zimbabwe. The population as at the last census (200I) was I.6 million. The capital city is Gaborone where the largest population of lawyers can be found. The Botswana legal system is a dual system of Common (Roman Dutch) law and customary law. Law Firms in Botswana are regulated by the Law Society, which was created in 1996 through an Act of Parliament. Every lawyer who practices in Botswana must be a member of the law society. The legal profession in Botswana is divided into attorneys and advocates, although this division is fluid, as they both have the right to access of all courts except the customary courts (Quansah, 200I). There are currently 87 law firms practicing in Botswana with a total of 162 law partners; in Gaborone, there are 59 law firms.

Information and communication technology (ICT) encompasses the use of both computers and communication technology in a seamless manner. Lawyers are not immune from the re-engineering process that is working its way through the rest of the world. Susskind (1996), a leading legal technological expert, predicts that in the future, law will function with digital information. Since law is largely information, law firms are expected to be at the centre of the organisational redesigned efforts based on information technology (IT). Perrit (1993), observes that lawyers are very much producers, processors, managers and purveyors of information. The main tasks of lawyers have been summarised as information collection and retrieval, communication of information, information management, research and evaluation of information (The Australian Law Reform Commission, 1999). Thus, it is suggestive that the lawyers' task can be facilitated by the use of ICTs. It is however worth noting that lawyers are cautious by their very nature and the profession where according to Schulte (1997), principles are forged over hundreds of years.

Lawyers in Botswana, like most lawyers elsewhere seem to have lagged behind, failing to understand and appreciate the vast changes that ICT are having on legal practice elsewhere. The general objective of the study was to find out what the lawyers' perceptions of ICT were, using Roger's theory of attributes of an innovation as determinants of the adoption

I. Madeleine Fombad, LLM.., M.LIS, is the Librarian at Tlokweng DaySpring School Gaborone, Botswana

2. Kgomotso Moahi, PhD, is Head of the Department of Library and Information Studies, University of Botswana, Gaborone, Botswana. 
of the innovation. It was also aimed at providing insights as to how far the concept of the digital lawyer (Katsh, 1995) is manifested in law firms in Gaborone.

The specific objectives of the study were to determine the lawyers' perception towards ICT, using Rogers' attributes of an innovation; identify the range of ICT utilized by law firms in Gaborone, Botswana; investigate the factors that promote or inhibit the adoption and use of ICT in these law firms.

This study aimed at providing some insight into the adoption and use patterns of ICT in law firms in Botswana. Such insight it was hoped, would provide Botswana lawyers with valuable information that will be helpful in creating an appropriate environment for change of attitude, the smooth introduction and acceptance of ICT as a productive business tool as they settle in the new information environment.

\section{Literature review}

The innovation-diffusion theory has been used to explain the adoption and the spread of new ideas and technologies (Robertson et al., 1996). It has been used to explain a wide variety of new concepts from the spread of rural technology amongst farmers to the adoption of innovative legislative measures amongst states of federations such as Australia, Canada, and the United States (Poel, 1976). The introduction of ICT into organizations can be considered to be an innovation (Cooper and Zmud, 1990; Kaplan, 1991; Thong and Yap 1995). The innovation-diffusion theory is therefore one way of understanding the attitude of lawyers towards the adoption and use of ICT in law firms.

Rogers (199I) talks of a number of attributes that can facilitate adoption of innovations: Relative advantage is the degree to which an innovation is perceived as better than what it supersedes. Generally, the relative advantage of an innovation as perceived by members of a social system is positively related to its rate of adoption. Compatibility is the degree to which an innovation is perceived as consistent with the existing values, past experiences and needs of potential adopters. Similarly, the compatibility of an innovation as perceived by members of a social system is positively related to the rate of adoption (Rogers, 1991). Trialability is the degree to which an innovation may be experimented with on a limited basis before full use. Observability deals with the degree to which the results of an innovation are visible to the potential adopters. In addition, the observability of an innovation as perceived by members of a social system is positively related to its rate of adoption (Rogers 1991). Rogers (1991) argued that the easier it is for individuals to see the results of an innovation, the more likely they are to adopt. Davidson et al. (2000) have gone even further to assert that the easier it is for lawyers to see the results of an innovation from peers, the more likely they are to adopt it. Complexity is the degree to which an innovation is perceived as difficult to understand and use. Evidently, the complexity of an innovation as perceived by members of a social system is negatively related to its rate of adoption (Rogers 1991).

Lawyers can be characterized in relation to their understanding and use of ICT in one of the following types: atheist, agnostic, believers or evangelist (Susskind, 1996). Sharing the same views, Katsh (1996), used the following terms: confused, ambivalent, mystified, fearful, attracted to, excited by, enthralled, to represent a description on how some lawyers perceive ICT. He opined that, while for some lawyers, cyberspace is already an exciting, useful and familiar place; one that may be used as often as the library or the court room, or may actually be a substitute for the library or courtroom; for other lawyers, however, what is occurring in cyberspace is deemed not relevant to their professional lives.

Law firms are at greatly varying levels of adopting new technologies. While there are few firms that have embraced ICT, the vast majority is yet to fully capitalize on the benefits technology can offer. American, British, Australian, Norwegian and Japanese lawyers possibly due to greater exposure to technology and increased competition exhibit much higher level of ICT use.

The changing nature of work opportunities afforded by electronic integration and the changing competitive climate, have all combined to provide organisations with compelling reasons to rethink their structures, roles and mission and the manner in which they carry out business (Galiers, 1992). Law firms have started to do this by adopting and using ICTs in all areas of their business and it is gradually becoming a necessity for all legal practitioners who want to sharpen their competitiveness and broaden their influence within the legal industry and the global economy. Therefore, like most other businesses, the practice of law is no longer location bound as international boundaries are being broken leading to an increase in collaborative legal practice worldwide Some analysts (Katsh, 1995; Granat, 1998; Susskind, 1996) predict that technology may soon change the lawyers' routines, challenge the inefficiencies as well as create opportunities for new forms of law firms and practice. One hallmark of the new economy is the need to define business in terms of the customer's changing needs. Today, defining a law firm from the producers' (lawyer's) point of view is simply no longer workable and will have vast implications for the practice of law and law firms in the future. ICT allows a law firm to differentiate itself along several critical dimensions: time, space, matter, substitution of electronic based information services for high priced labour, elimination of intermediaries through direct contact with customers, and the 
customization of services to the particular needs of the individual client (Vernon et al. 1999). Thus, the rise of the electronic economy and the increased use of IT in legal practice will have unanticipated consequences as technology shifts from being the servants of our wishes to the master of our destiny. According to Granat (1998), technology is causing lawyers to experience extraordinary changes and challenges that will have lasting impact on the structure of the legal profession and the approach to legal practices.

The methods used to study ICT and legal practice, have largely involved the use of survey design and questionnaires and interviews as data collection instruments. In the reviewed literature, Duncan (1997), studying the impact of ICT on small legal practices in Scotland, used a multiple case study research design, semi-structured interviews and questionnaires. Gottschalk (1999) studying IT used for knowledge management in law firms in Norway used a survey research design, structured interviews and questionnaires. Wall and Johnstone (1997), studying IT and the shaping of legal practice in the UK used the survey research design and the questionnaire. And Wall (1998), in a follow up study on the impact of IT on the legal practice in the UK used the survey research design and the questionnaire. What has been noted in these methodologies is that, except Duncan (1997) who used the multiple case study approach all the other researchers used the survey research design. Also, it is only Duncan (1997) and Gottschalk (1999), who mixed both questionnaires and interviews as the data collection instruments.

\section{Research Method and procedure}

The research design adopted for the study was the survey research design. Currently there are 87 law firms operating in Botswana with a total of 162 partners. Most of these firms are situated in the capital city of Gaborone, and thus the study was conducted in the city. A total of 114 partners in the 59 firms located in Gaborone were surveyed. The return rate of the questionnaire was 83 of the 114 partners, representing a $73 \%$ response rate. Since there are 59 firms and a total of II 4 partners in Gaborone, a census of the whole population was taken. Questionnaires were administered to all the partners. One partner per firm was also interviewed using a semi-structured interview guide. In each of these firms the purposive sampling technique was used to select the partner to be interviewed. The choice of a partner to be interviewed depended on the willingness of the partner to participate in the study and any other insight that was to be gained. We used a combination of instruments, open and closed-ended questionnaires and semi-structured interviews. The combination of these two instruments enabled the strengths of one method to counteract the weaknesses of another (Bryman, 1989; Easterby-Smith et al., 1991). It also generated a rich profile on the adoption and use patterns of ICT in the law firms. The questionnaire was the primary data collection instrument, through which the opinions, feelings, experiences, and views of lawyers towards the adoption and use patterns of ICT were obtained. All data was collected over a period of two and the half months. Data collection commenced on the $28^{\text {th }}$ January 2002 and was completed by $15^{\text {th }}$ April 2002.

\section{Results}

The section focuses on characteristics of respondents, and their perceptions about the use of ICT in law firms using to Rogers' attributes of an innovation.

\subsection{Characteristics of the respondents}

The majority $(53.0 \%)$ of the respondents were within the age range of $31-40$ Years. Male lawyers were in the majority (7I or $85.5 \%$ ), whilst 12 (14.5\%) were female. Forty-eight (75.8\%) had computer experience, whilst 35 (42.2\%) had no experience prior to working with computers. The level of education of the lawyers varied from the basic undergraduate degree $(58$ or $69.5 \%)$, with $25(30.1 \%)$ having a postgraduate qualification. The majority had practiced law for a period between 10 to 25 years $(28.5 \%)$ whilst $6(7.2 \%)$ were within I-3 year range, $18(21.6 \%)$ within 4-6 year range, II (13.2\%) within 7-9 year range.

\subsection{Lawyers' perceptions of ICT using to Rogers' attributes of an innovation}

For each element of perception, a number of factors were identified. Respondents were asked to rate each of the factors on a five point scale of (I) strongly agree, (2) agree, (3) uncertain, (4) disagree, (5) strongly disagree. For ease of interpretation and greater appreciation of the significance of the results, the responses for "strongly agree" and "agree" were combined to form "agree" and the responses for "disagree" and "strongly disagree" were combined to form "disagree"; while the responses for uncertain were left as they were.

\subsection{Lawyers' perception on ICT providing relative advantage}

According to the findings (Table I), the majority of the respondents' perception was that ICT could provide relative advantage. This was shown by their positive responses to 12 questions presented to them. 72 (86.7\%) agreed that ICT could provide competitive advantage to their firms; 59 (7I.1\%) saw it as providing economic gain. Convenience was 
agreed upon by 77 (92.8\%); and the fact that legal research could be facilitated and improved was agreed on by 76 (91.6\%). Seventy five (90\%) felt that ICT could improve their efficiency and would free them from the more routine processes. They felt that it could improve information management: $65(78.3 \%)$ felt it could assist in the retrieval and management of unreported cases, ICT could facilitate knowledge management $(66-79.5 \%)$; However, respondents were not too certain that ICT could reduce information overload, only 46 (55.4\%) agreed to the statement, 32 (37.3\%) actually admitted uncertainty, and 4 (4.8\%) totally disagreed with the statement.

Table I Lawyers' Perception on ICT providing Relative Advantage $(n=83)$

\begin{tabular}{lcccccc}
\hline & \multicolumn{2}{c}{ Agree } & \multicolumn{2}{c}{ Uncertain } & \multicolumn{2}{c}{ Disagree } \\
\hline & No & $\%$ & No & $\%$ & No & $\%$ \\
Provides competitive advantage & 72 & 86.7 & 11 & 13.3 & & 2.4 \\
Provides economic gains & 59 & 71.1 & 19 & 22.9 & 2 & \\
It is convenient & 77 & 92.8 & 4 & 4.8 & & \\
It facilitates legal research & 76 & 91.6 & 7 & 8.4 & & \\
It improves efficiency & 75 & 90.0 & 7 & 8.4 & & \\
It frees lawyers from routine processes & 50 & 60.2 & 24 & 28.9 & 7 \\
It aids data storage and retrieval of unreported cases & 65 & 78.3 & 18 & 21.7 & & 4.8 \\
It facilitates knowledge management & 66 & 79.5 & 17 & 20.5 & & 7.2 \\
It reduces information overload & 46 & 55.4 & 31 & 37.3 & 4 \\
It facilitates communication with clients & 58 & 69.9 & 19 & 22.9 & 6 \\
It facilitates communication with other lawyers & 69 & 83.1 & 12 & 14.5 & 2 & 2.4 \\
It facilitates file management & 72 & 86.7 & 11 & 13.3 & & \\
\hline
\end{tabular}

\subsubsection{Lawyers' perception on the compatibility of ICT}

The perception of ICT as an innovation compatible with the work of lawyers was not as strong as that of it providing relative advantage. In general, the lawyers in this study felt that the use of ICT could be compatible with their work, although the small number somehow shows that they were not all completely convinced. Table 2 shows that 49 (59\%) disagreed with the statement that it would be difficult to make the change to ICT. Fifty three $(69.3 \%)$ stated that they do, in fact, need to use ICT in their work, and (57 or $68.7 \%)$ ) felt that ICT would not make lawyers redundant. Another 54 $(65.5 \%)$ did not doubt the value and efficiency of computers in legal work. However $45(52.2 \%)$ felt that they could succeed without ICT against 26(3I.3\%) who felt otherwise. This showed that even though they perceived the technologies to be compatible, they felt they could survive without them. Less than half (32 or $38.6 \%$ ) said they were unaware of how ICT could be utilized in the legal process, and only $35(42.2 \%)$ were aware. This probably points to the need for education of the lawyers. As could be expected, 35 (42.2\%) were concerned about the security of information once ICT were employed, 27 (25.3\%) were uncertain on the issue, and 21 (25.3\%) did not feel security was an issue.

Table 2 Lawyers' Perception on the Compatibility of ICT $(\mathrm{N}=83)$

\begin{tabular}{lcccccc}
\hline & \multicolumn{2}{c}{ Agree } & \multicolumn{2}{c}{ Uncertain } & \multicolumn{2}{c}{ Disagree } \\
\hline & No & $\%$ & No & $\%$ & No & $\%$ \\
It is difficult to change to ICT & 14 & 16.9 & 20 & 24.1 & 49 & 59.0 \\
Can still succeed without ICT & 45 & 52.2 & 12 & 14.5 & 26 & 31.3 \\
Do not need them in the work they do & 15 & 18.1 & 12 & 14.5 & 53 & 69.3 \\
Lawyers are concerned about the security of information & 35 & 42.2 & 27 & 32.5 & 21 & 25.3 \\
ICT may make lawyers redundant & 10 & 12.0 & 16 & 19.3 & 57 & 68.7 \\
Doubts of the value and efficiency of computers in legal work & 12 & 14.5 & 17 & 20.5 & 54 & 65.5 \\
Not aware of how ICT can be used in the legal process & 32 & 38.6 & 16 & 19.3 & 35 & 42.2 \\
\hline
\end{tabular}

\subsubsection{Lawyers' perception on the trialability of ICT}

Trialability is the degree to which an innovation may be experimented with on a limited basis before it can be adopted. Four questions were provided in order to determine the respondent's perceptions. The first question was whether respondents felt it was better to start off by experimenting with ICT before adopting it. The majority (64; or $77.1 \%)$ of the respondent said "yes" and 19(22.9\%) "No". In the second question, respondents were asked to give reasons for indicating either a "yes" or "no" in the previous question. Slightly more than half of the respondents (47 or $56.6 \%$ ) indicated that one cannot adopt something one is not familiar with, followed by $45(54.2 \%)$ who revealed that it is better to assess the pros and cons of ICT before risking investment (see Table 3). The third question was aimed at finding out 
whether respondents started off by experimenting with ICT before adopting it. The majority $5 \mathrm{I}(6 \mathrm{I} .4 \%)$ indicated that they started off by experimenting with ICT before adopting it, against $27(32.5 \%)$ who indicated that they did not. The fourth question was how respondents started off in the adoption of ICT in their firms. The results reveal that $4(4.8 \%)$ of the respondents started off by using demonstration models, the majority $67(80.7 \%)$ started off by using just the word processor, and $4(4.8 \%)$ started off by acquiring CD-ROM for legal research. In the "other" option, 3(3.6\%) of the respondents indicated that they started off by using word processor and accounting packages, another $3(3.6 \%)$ indicated that they started off by using word processor and CD-ROM and 2(2.4\%) started off by using demonstrator models and word processors.

Table 3 Reasons to start off experimenting with ICT before adopting it $(\mathrm{N}=83)$

\begin{tabular}{lcc}
\hline & Frequency & Percent \\
\hline To assess the pros and cons of ICT before risking investment & 45 & 54.2 \\
One cannot adopt something one is not familiar with & 47 & 56.6 \\
The way to be comfortable with a new toy is to play with it & 6 & 7.2 \\
It enable one to tailor ICT to the law firm & 6 & 7.2 \\
One would be accustomed to how ICT function & 3 & 3.6 \\
\hline
\end{tabular}

\subsubsection{Lawyers' perception on the observability of ICT}

Observability of an innovation deals with the degree to which the results of an innovation are visible to potential adopters. It was noted in the literature that the visibility of the effectiveness of ICT in other firms, peer opinion as to the effectiveness of ICT and previous positive experience with ICT were factors that determine the observability of an innovation. Table 4 shows the fact that ICT was seen to be effective in other firms was rated highest by $58(69.9 \%)$ who agreed against $5(6.0 \%)$ who disagreed and $14(16.9 \%)$ who were uncertain. This was closely followed by the respondents' previous positive experiences with ICT where $57(68.7 \%)$ agreed against I(I.2\%) who disagreed and $22(26.5 \%)$ who were uncertain. Peer opinion as to the effectiveness of ICT was the third rated factor with $47(56.6 \%)$ respondents who agreed, $10(12.0 \%)$ who disagreed and $19(32.9 \%)$ who were uncertain.

Table 4 Respondents' Perceptions of ICT with Regards to the Observability of ICT $(\mathrm{N}=83)$

\begin{tabular}{lccccccc}
\hline & \multicolumn{2}{c}{ Agree } & \multicolumn{2}{c}{ Disagree } & \multicolumn{2}{c}{ Uncertain } \\
\hline & No & $\%$ & No & $\%$ & No & $\%$ \\
The visibility of the effectiveness of ICT in other firms & 58 & 69.9 & 5 & 6.0 & 14 & 16.9 \\
Peer opinion as to the effectiveness of ICT & 47 & 56.6 & 10 & 12.0 & 19 & 22.9 \\
Previous positive experience with ICT & 57 & 68.7 & I & 1.2 & 22 & 26.5 \\
\hline
\end{tabular}

4.2.5 Lawyers' perceptions on the complexity of ICT

Complexity of an innovation is the degree to which an innovation is perceived as difficult to understand and use. Table .5 shows that only $23(27.5 \%)$ of the respondents agreed that ICT were complicated to learn, $4(4.8 \%)$ were uncertain, and a majority, 56(67.5\%) disagreed. As to whether ICT are difficult to understand and use, only 19(22.9\%) of the respondents agreed, 6(7.2\%) were uncertain and the majority 58(69.9\%) disagreed. Most of the respondent, $46(55.4 \%)$ agreed that ICT change drastically and quickly, I8(21.7\%) were uncertain and I7(20.5\%) disagreed. With regards to whether respondents are afraid of using ICT, $2 \mathrm{I}(25.3 \%)$ agreed, $5(6.0 \%)$ were uncertain, and the majority $55(66.3 \%)$ disagreed. For the respondents' perceptions as to whether the Internet is confusing, $16(19.3 \%)$ agreed, $9(10.8 \%)$ were uncertain, and the majority 55(66.3\%) disagreed. With regards to whether ICT are difficult to install and use, $21(25.3 \%)$ agreed, 16(19.3\%) were uncertain and the majority, 46(55.4\%) disagreed. A majority of the respondents, $46(55.4 \%)$ agreed that they had no time to study how to use ICT, $8(9.6 \%)$ were uncertain and $29(34.9 \%)$ disagreed.

Table 5 Lawyers' Perception on the Complexity of ICT $(\mathrm{N}=83)$

\begin{tabular}{lccccccc}
\hline & \multicolumn{2}{c}{ Agree } & \multicolumn{2}{c}{ Uncertain } & \multicolumn{2}{c}{ Disagree } \\
\hline & No & $\%$ & No & $\%$ & No & $\%$ \\
ICT are complicated to learn & 23 & 27.7 & 4 & 4.8 & 56 & 67.5 \\
ICT are difficult to understand and use & 19 & 22.9 & 6 & 7.2 & 58 & 69.9 \\
ICT change drastically and quickly & 46 & 55.4 & 18 & 21.7 & 17 & 20.5 \\
Afraid of using ICT & 21 & 23.3 & 5 & 6.0 & 55 & 66.3 \\
The Internet is confusing & 16 & 19.3 & 9 & 10.8 & 55 & 66.3 \\
ICT are difficult to install and use & 21 & 25.3 & 16 & 19.3 & 46 & 55.4 \\
No time to study how to use ICT & 46 & 55.4 & 8 & 9.6 & 29 & 34.9 \\
\hline
\end{tabular}




\subsubsection{Kinds of ICT used and level of usage in law firms}

All 83 firms indicated that they use ICT in their firms. The respondents were asked to indicate if the decision to use ICT was taken as a conscious firm policy, rather than by default, and $52 \%$ agreed it was by default. Only one (I) firm had started using ICT as far back as 1980, and 15.7\% as far back as 1997. On the types of hardware used in the firms, the study revealed that $88 \%$ used personal computers (PCs); $31.3 \%$ used Apple Desktops; and $16.9 \%$ used mainframes. Various types of software were used: word processing (83\%), spreadsheets (53\%), standard forms precedents $(74 \%)$, and presentation software $(7.2 \%)$. Thirty-two $(38.6 \%)$ of the respondents indicated that they were using electronic diaries and only $18(21.7 \%)$ of the respondents indicated that they were using communication systems. However, none of the firms reported use of litigation support systems, knowledge management systems, and voice recognition systems. In the "other" option category, 7(8.4\%) of the respondents indicated that they used Law Plan - a highly specialized package designed for law firms. Clearly, most of the law firms in Gaborone, Botswana have adopted ICT for basic applications, despite the positive perception of ICT as an innovation. Thus, the observation is that the levels of usage of ICT in the law firms in Gaborone, Botswana were mainly for back-office operations (word processing and other administrative functions).

\subsubsection{Level of adoption of hardware and software}

The total number of hardware available in the law firm, no matter the type is important at determining the firms' level of investment and thus adoption of ICT. Respondents were asked to indicate if they all had access to computers in the firm. The results showed that only $20(24.1 \%)$ had access to their own computers while the majority, 63(75.9\%) did not have access to computers. From these findings it is clear that the majority of the law firms are yet to adopt computers that will be made available to all in the firm.

Software such as word-processing, spreadsheets, standard form/precedents, presentation programs, and electronic diaries were grouped together and considered as "basic office applications". Software that were considered more specialized and therefore more expensive such as, litigation support systems, knowledge management systems, voice recognition systems, law plan, time slips and communication software were grouped as "specialized software." A frequency distribution of the software use revealed that most of the respondents $77(92.8 \%)$ had adopted ICT just for "basic applications" against 6(7.2\%) who had adopted ICT for more specialized applications.

\subsubsection{Evolving concept of a digital lawyer manifestation in Botswana}

The respondents were interviewed. From these interviews, it emerged that in spite of the presence of computers in all the firms, the secretaries and the support staff did word-processing and other back-office activities in the law firms. The lawyers still drafted the legal documents by hand and dictated notes. The most common medium of communication between the lawyers and the clients in the law firms were through telephones and faxes. One respondent indicated that he was so ignorant in the use of computers that he had to rely all the time on the secretaries when there is a need to contact a client by e-mail. Lawyers still counsel clients on a one to one basis and represent them physically in the courts. Technologies like video conferencing and teleworking are not available. Very few interviewees indicated that they ever searched databases in the course of their legal research. Nevertheless, two interviewees actually acknowledged the benefits and opportunities that exist in the use of the Internet and legal databases for legal research. Most of the interviewees rely very much on journal articles and print technology for research purposes and are subscribed annually to most legal journals of interest to them.

\subsubsection{Factors encouraging the adoption and use of ICT in the law firms}

The potential benefit of the use of ICT was rated as the most important factor that influences the adoption and use of ICT by $66(79.5 \%)$ of the respondents. The need for strategic planning in the firm was the second rated by $64(77.1 \%)$ respondents. Visibility of the effectiveness of ICT in other firms was rated third by $58(69.9 \%)$ respondents. The respondents' previous positive experience with ICT was rated as the fourth factor that influenced the adoption and use of ICT by $57(68.7 \%)$ respondents. Peer opinion as to the effectiveness of ICT was rated as the fifth factor that influences the adoption and use of ICT by $47(56.6 \%)$ respondents. Collaboration amongst lawyers was rated as the next factor by $42(50.6 \%)$ respondents, while $15(18.1 \%)$ disagreed and 17(20.5\%) were uncertain. A strong top partnership support and the availability of strong internal support were respectively considered as the least important factors that influenced the adoption and use of ICT in the law firms. Forty-one or (49.4\%) agreed that strong top partnership support, influenced them, 14 (16.9\%) disagreed, and $22(26.5 \%)$ were uncertain. With regard to the availability of strong internal support, $40(48.2 \%)$ agreed that it influenced the adoption and use of ICT, I5(I8.I\%) disagreed and I7(20.5\%) were uncertain. Pressure of competition from other firms and para professionals was the least significant factor that influenced 
the adoption and use of ICT. Thirty-nine or $47.0 \%$ agreed, against $23(27.7 \%)$ who disagreed and I2(I4.5\%) who were uncertain.

Table 6 Factors Influencing the Adoption and Use of ICT (N=83

\begin{tabular}{lcccccc}
\hline & \multicolumn{2}{c}{ Agree } & \multicolumn{2}{c}{ Disagree } & \multicolumn{2}{c}{ Uncertain } \\
\hline & No & $\%$ & No & $\%$ & No & $: \%$ \\
The visibility of the effectiveness of ICT in other firms & 58 & 69.9 & 5 & 6.0 & 14 & 16.9 \\
Peer opinion as to the effectiveness of ICT & 47 & 56.6 & 10 & 12.0 & 19 & 22.9 \\
Collaboration amongst lawyers & 42 & 50.6 & 15 & 18.1 & 17 & 20.5 \\
Pressure of competition from other firms and para-professionals & 39 & 47.0 & 23 & 27.7 & 13 & 14.5 \\
The need for strategic planning & 64 & 77.1 & 5 & 6.0 & 14 & 16.9 \\
Availability of strong internal support & 40 & 48.2 & 15 & 18.1 & 17 & 20.5 \\
Strong top partnership support & 41 & 49.4 & 14 & 16.9 & 22 & 26.5 \\
Potential benefits of ICT & 66 & 79.5 & - & - & 16 & 19.3 \\
Previous positive experience with ICT & 57 & 68.7 & 1 & 1.2 & 22 & 26.5 \\
Mismatch between actual and potential performance in the firm & 44 & 53.0 & 9 & 10.8 & 26 & 31.3 \\
\hline
\end{tabular}

4.2. I0 Factors impeding the adoption and use of ICT in the law firms

A list of possible factors that impede the adoption and use of ICT was provided to the respondents for their rating (see Table 7). The lack of in-house expertise was rated highest, 74(89.2\%) indicated that this impedes the adoption and use of ICT. The second rated factor was the high cost charged by ICT consultant $72(86.6 \%)$, respondents thought it was an impediment. Lack of ICT skills was the third rated factor by $69(83.1 \%)$ of the respondents. The high cost of specialized legal systems was rated fourth by $60(72.3 \%)$ respondents. Limited financial resources were the fifth rated factor by $58(69.9 \%)$ respondents. Dissatisfaction with ICT consultants was rated sixth by $57(68.8 \%)$ respondents. The lack of user manuals was considered the least of the factors only by $37(44.6 \%)$ respondents. The firms' policy was not seen to impede the adoption and use of ICT, only II $(13.3 \%)$ of the respondents indicated that the firms' policy impedes; the majority 56(67.5\%) noted that it did not impede and $16(19.3 \%)$ were uncertain.

Table 7 Factors Inhibiting the Adoption and Use of ICT $(\mathrm{N}=83)$

\begin{tabular}{lcccccc}
\hline \multicolumn{1}{c}{ Factors } & \multicolumn{2}{c}{ Does not Impede } & \multicolumn{2}{c}{ Impede } & \multicolumn{2}{c}{ Uncertain } \\
\hline & No. & $\%$ & No. & $\%$ & No. & $\%$ \\
High cost of specialized systems & 15 & 18.1 & 60 & 72.3 & 6 & 7.2 \\
Lack if in-house expertise & 7 & 8.4 & 74 & 89.2 & & \\
Limited financial resources & 16 & 19.3 & 58 & 69,9 & 7 & 8.4 \\
Lack if ICT skills & 9 & 10.8 & 69 & 83.1 & 5 & 6.0 \\
Lack of user manuals & 25 & 30.1 & 37 & 44.6 & 21 & 25.3 \\
Firms Policy & 56 & 67.5 & 11 & 13.3 & 16 & 19.3 \\
High cost charged by ICT Consultants & 9 & 10.8 & 72 & 86.7 & 2 & 2.4 \\
Dissatisfaction with ICT Consultants & 19 & 22.9 & 57 & 68,7 & 7 & 8.4 \\
\hline
\end{tabular}

\section{Discussion}

The respondents in this study perceived ICT as relatively advantageous. They felt that the use of ICT would provide them with competitive advantage. Although this was the case, there were indications that most of them do not perceive ICT as something that affects their professional success. This last point may explain why they seem to have missed many of the changes that increased use of ICT could have in legal work. Again, although most of the respondents justified relative advantage of ICT by reference to efficiency and effectiveness, most felt they could still succeed without the use of ICT.

The respondents seem to have had a positive perception of the compatibility of ICT with their work. That is, they felt that the adoption and use of ICT were compatible to the social values of the legal profession. This, however, did not translate to a high rate of adoption of ICTs because most of the respondents were using ICTs just for back-office operations. However, the literature suggests that, the adoption and use of ICTs by lawyers is not compatible with the existing social values of the legal profession (Balogh and Pannonius, 1997; Granat, 1998; Stanfield, 1998; Clark and Economides, 1998; Newcombe, 1998; Lauritsen, 1999).

Trialability is the degree to which an innovation may be experimented with on a limited basis. Generally, the trialability of an innovation as perceived by members of a social system is positively related to its rate of adoption (Rogers, 1991). 
Our findings do not appear to totally support this generalisation because though the respondents' perception of trialability seemed to be positive, they have just started adopting ICT.

Observability deals with the degree to which the results of an innovation are visible to the potential adopters. Generally, the observability of an innovation as perceived by members of a social system is positively related to its rate of adoption (Rogers 1991). Rogers (1991) argued that the easier it is for individuals to see the results of an innovation, the more likely they are to adopt. Davidson et al. (2000) have gone even further to assert that the easier it is for lawyers to see the results of an innovation from peers, the more likely they are to adopt it. He contended that, the most fruitful method of getting someone actually started on using ICTs was peer interaction; the adopter and the adoptee often acted as "buddies" in demonstrating the rudiments of using ICTs and answering questions in a comfortable environment. It is worth noting that the factors identified as determining the respondents' perception of an innovation as observable are similar to some of the factors that encourage the adoption and use of ICTs in the firms. Though the respondents seemed to have demonstrated a positive perception towards the observability of an innovation, this did not translate into high rates of adoption of ICTs in the law firms because ICTs were used mainly for back-office operations.

Complexity is the degree to which an innovation is perceived as difficult to understand and use. Generally, the complexity of an innovation as perceived by members of a social system is negatively related to its rate of adoption (Rogers 1991). It was earlier suggested in the literature review that lawyers' perception of an innovation as complex would negatively influence their rate of adoption of ICTs (Stanfield, 1998; Lauritsen, 1999; Armitage, 1997; Macaulay, 1993; Zales, 2000; Morris, 1996). In this study the respondents seemed to have perceived ICTs as not being complex, though their rate of adoption of ICTs was low as many of them used ICTs just for back-office operations.

The study found that in spite of the positive perceptions of ICT in legal work, there were other factors that militated against wholesale adoption of ICT in legal work. These factors were identified as the lack of expertise and skills, the high charges of IT consultants, the high cost of specialized legal systems, limited financial resources, ICT phobia, lack of information about appropriate software, and the apparent unwillingness of lawyers to use and exploit the full benefits of ICT.

Another interesting finding was that the majority of the respondents did not consider the concerns for the security of information as a factor that impeded the adoption and use of ICT. However, lawyers have always been concerned or even obsessed with security from protecting clients' documents, to shielding privileged legal advice, to safeguarding accounting information (Wendy Tech Articles, 1998). They tend to be more concerned in securing their data than other businesses and thus fear the liability for professional malpractice that might result from unauthorized access to the firms' documents.

\section{Conclusion}

This research paints a picture of a profession that has not fully embraced ICT. It shows that the adoption and use of ICT in the law firms in Gaborone, Botswana is still at its infancy. Currently, all the firms are making some basic use of ICT such as word-processing and accounting packages, but this is a mere lip service when compared to the possibilities and opportunities of ICT in legal work such as preparing documents and keeping diary notes by simply talking to the computer, conducting research beyond the bounds of a limited practice library, reading a judgment over the Internet immediately after it has been handed down, attending on the client whom one has not seen, teleworking, virtual firms etc. Though many other business communities and professions in Botswana have fully embraced ICT, lawyers as the ultimate masters of information are yet to make optimal use of ICT. As in the wider business world, some of the law firms are keen to embrace the latest ICT while others take a more cautious attitude, perhaps regarding ICT as a necessary evil. This observation is borne out by the findings in this study.

This study recommends the following:

I. The legal educational system should play a key role in enabling lawyers to appreciate the importance of ICTs.

2. The law department at the University of Botswana should offer courses in information technology, and fit in computer related subjects into the continuing legal education courses.

3. Lawyers should find time to acquire computer skills. Though some might still feel it is a waste of time, they will later realize that the time spent in acquiring these skills was a good investment to their profession. They should collaborate with the Law Society, which can organize computer seminars for lawyers and also short courses in basic computer skills. Paying attention to the Internet and what it has to offer is a key to practicing law in the years ahead.

4. Law firms should engage technical expertise temporally or permanently who will be able assist them in the adoption and use of ICT, appreciate and advise them on the benefits of emerging technologies for the legal profession, and also are able to assess the uptake of any new technology in the firm. 


\section{References}

Armitage, N. (1997). The Use of Teleworking Technologies by UK Law Firms; Davies\& CoBILETA Conference paper.[Online] Available: http://members.aol.com/davislawuk/bileta.html. Accessed 6 October 2005

Australian Law Reform Commission (1999). Technology and Dispute Resolution - an overview, .[Online] Available: http:// www. austlii.edu.au/au/other/asrc/publications/issues/23/02.html

Balogh, Z. and Pannonius, J. (1997). Information Technology in Law in Hungary. Law Technology Journal, 3(I) [Online] Available: http://www.law.warwick.ac.uk/ltj3-Ig.html.

Bryman, A. (1989). Research Methods and Organisational Studies. Contemporary Social Research Series, 20, London, UK, Routledge.

Clark, A. and Economides, K. (1998). Technics and Praxis: Technological Innovation and Legal Practice in Modern Society. Sociologia del diritto, I: 40-65.

Cooper, R.B. and Zmud, R.W. (1990). Information Technology Implementation Research: a Technological Diffusion Approach. Management Science, 36 (2): $123-139$.

Davidson, A. and Mcgregor-Lowndes, M. (2000). Innovation Diffusion Theory: The Internet and the Legal Office. AustLII. [Online] Available: http://www.uq.eddu.au/ laadavid/innovationtheory2.html.

Duncan, P. (1997) Information Technology and the Scottish Legal Profession: Innovators versus the Majority. 12 ${ }^{\text {th }}$ BILETA Conference, The Future of Legal education and Practice, [Online] Available: http://wwww.law.warwick.ac.uk/confs/97-4.htm.

Easterby-Smith, M. Thape, R. and Lowe, A (199I). Management Research: An Introduction. London, UK, Sage.

Gottschalk, P. (1999). Use of IT for Knowledge Management in Law Firms. The Journal of Information, Law and Technology (ILT), [Online] Available: http://elj.warwick.ac.uk/jilt/99-3/gottschalk.html.

Granat, R.S. (1998). Training Lawyers for a Digital Age. $12^{\text {th }}$ Annual ABA Techshow98, March 28 [Online] Available: http:// wwww.digtal-lawyer.com/retrain.html.

Kaplan, B. (199I). Models of Change and Information Systems Research in Nissen H-E, Klein H K and Hirschheim. Information Systems Research: Contemporary Approaches and Emergent Traditions. Amsterdam, Netherlands, Elsevier Science.

Katsh, M. E. (1995). Law in the Digital World. [Online] Available: http://www.umassp.edu/legal/dw control.html.

Katsh, M. E. (1996). Lawyers in the Networld. Journal of Computer Mediated Communication, 2 (2), part2 of special issue, [Online] Available: http://www.ascusc.org/jemc/vol2/issue2/katsh.html

Lauritsen, M. (1999). The Computer as a Lawyer -Saving Device. Law Practice Management Magazine, Nov/Dec [Online] Available: ttp://www.abanet.org//pm/magazine/998lauritsen.html.

Macaulay, S. (1993). The Future of American Lawyers. Sociologia del diritto, 2: 50-69.

Morris, A. (1996). Why Lawyers Need Email. Law Society Journal, 34 (II): 39.

Newcombe, T. (1998). Integrated Justice: The Burden of Proof. Government Technology, [Online] Available: www.govtech.net/ gtmag//998/dec/cover/cover/.htm

Perrit, H. (1993). How to Practice Law with Computers. International Journal of Law and Technology, 2(I): 107.

Presidential Task Group for a Long Term Vision for Botswana, (1997) A Framework for a Long Term Vision for Botswana, Gaborone.

Poel, D.H, (1996). The Diffusion of Legislation Amongst the Canadian Provinces Statistical Analysis, Canadian Journal of Political Science, 9(4), 605.

Quansah, E.K. (200I). Introduction to Botswana Legal System $3^{\text {rd }}$ edition. Pula Press.

Robertson, M, Swan, J. and Newell, S. (1996). The Role of Networks in the Diffusion of Technological Innovations. Journal of Management Studies, 33 (3): 339-359.

Rogers, E.M. (1991). Diffusion of Innovations. New York, USA Free Press 3rd ed.

Schulte, R. (1997). Paul Hilder: IT in the Solicitor's Office. London. Blackstone Press.

Stanfield, A. (1998). Dinosaurs to Dynamos Has The Law Reached its Technological Age? University of NSW Law Journal, 2 I (2).

Susskind, R (1997). Information Technology and the Future of Lawyers. Journal of the Law Society of Scotland, 42 (I) 6-8.

Thong, J.Y.L. (1995). CEO Characteristics, Organisational Characteristics and information Technology Adoption In Small Business. International Journal of Management Science, 23(3): 429.

Wall, D.S. and Johnstone, J. (1997). The Industrialization of Legal Practice and the Rise of the New Electric Lawyer: The Impact Of Information Technology Upon Legal Practice in the UK. Journal of the Sociology of Law, 25: 95- II 6.

Wall, D.S. (1998). Information Technology and the Shaping of Legal Practice in the UK. I $3^{\text {th }}$ BILETA Conference: "The Changing Jurisdiction", 27-28 March, [Online] Available: http://www.bileta.ac.uk/98papers/walls.html

Zales, N.C. (2000).Elawyering. Lawyers Meet Encryption SoftwareWysiwyg:///33/ http://www.abanet/elawyering /resources/ encrypt_zales.htm 